\title{
EDUARDO MILÁN
}

\section{Una nueva generación}

Cuando el poeta argentino Arturo Carrera (1949) publicó su poemario Arturo y yo (Buenos Aires, Sudamericana, 1983), fue notoria la marca de una generación poética nueva que aparecía en el aire latinoamericano. En el título mismo de ese libro estaba patente un recurso utilizado por los nuevos poetas: la metonimia, que vendría a sustituir a la metáfora. como figura totémica para la poesía en América Latina. En efecto, la metáfora ha sido, desde las vanguardias hasta aquí en forma patente, el tropo por antonomasia para la poesía, casi una condición sine qua non para que se pudiera hablar de poesía en estas tierras. El fenómeno alcanza su máximo grado de esplendor con el desvelamiento de las cenizas de Góngora por obra y gracia de la generación del 27 español. Pero también antes, entre los herederos de la Vanguardia en América Latina (recordar Trilce de César Vallejo, Altazor de Vicente Huidobro o las mismas Residencias de Neruda) o, también posteriormente, con la obra completa de Lezama Lima y gran parte de la poesía de Octavio Paz, la metáfora era casi el equivalente de la figuración poética. Tal vez el aviso patente de un cambio en la manipulación tropológica de los nuevos poetas latinoamericanos fue el libro del poeta peruano Rodolfo Hinostroza, Contra Natura, publicado en 1970. Una mayor atención al lenguaje hablado rehuyó al efecto literalizante que impone la metáfora como figura de corte, como figura que impone una temporalidad excesivamente presente. Uno de los efectos característicos de la metáfora es la fijación de un aquí textual, que produce, al fracturar la cadena sintáctica, la conformación de un espacio pétreo, fundacional. Metáforas son cristalizaciones, figuras de rigidez que producen el simulacro de una detención temporal. La metonimia, por el contrario, es una figura de desplazamiento que sigue el procedimiento de rozar el objeto y continuar, sin producir alteraciones profundas en la sintaxis. Mejor, se acopla a la cadena y mantiene el ritmo de la frase intacto. Un ejemplo claro de poema eminentemente metonímico es el largo texto del argentino Néstor Perlongher (1949), que bajo el nombre de Cadaveres pasa revista, aplicando un riguroso esquema rizomático en la articulación del poema, a los últimos años de la historia de Argentina. Naturalmente que una serie de características no menos importantes que la fluidez sintáctica acompañan el procedimiento metonímico. Algunas de ellas: una tentación narrativa cada vez más patente, pautada por la búsqueda de un tema central, que termina convirtiendo el poema en una suerte 
de relato (condición que la vanguardia y sus herederos habían abandonado); el recurso a la parodia, tanto del texto, de la Historia (que también puede ser la historia de la literatura) como del autor mismo. Este último recurso, la autopàrodia, es una de las características más sobresalientes de la nueva poesía. Más que un alejamiento, se trata de un diálogo o de una recuperación de un problema que las vanguardias habían soslayado como condición de la Modernidad poética: la desaparición, casi por elipsis textual, del yo poético, dada por una búsqueda de invisibilidad del autor y por una necesidad de transformar el poema en un objeto ficticio en pie de igualdad con los "objetos naturales" del múndo. En el poema de vanguardia, en el poema "moderno", no había titular del texto: el texto era su propio autor y se hacía y deshacía por obra de un demiurgo ausente. En los nuevos textos todos hablan: la primera persona del singular, el nombre del autor y su apellido o una serie de "voces" utilizadas para resaltar el simulacro del hablante poético ya que, al fin y al cabo, nadie -ni siquiera el texto- pued adjudicarse los derechos de la voz poética. Esta anulación del concepto de productor del texto es patente en otro de los nuevos poetas, el uruguayo Roberto Echavarren, que en sus dos libros La planicie mojada y Animalaccio desborda por completo el concepto de titularidad y convierte sus textos en una suerte de polifonía fraseológica. En el fondo de esta revisión o crítica de la vanguardia hay un nuevo planteo de ciertos problemas que la vanguardia misma, por condición de su euforia, solamente atisbó. Uno de los problemas más claros es el de la identidad del texto. En efecto, la vanguardia, al asumir al yo poético debajo del texto, sólo simuló resolver el problema ya que al ocultarse el yo poético, por un efecto de mímesis en el texto, terminaban hablando el mundo, la realidad, o como quiera denominarse al ordenamiento de palabras en el poema. Pero la ecuación subyacía latente: yo=mundo. Ahora la ecuación se ha borrado tal vez por una sobresaturación autoral: todos hablan, todas las voces, todos los textos, un efecto que remarca que ahora sí, cuando todos tienen la palabra, cuando todos saben (en la crisis de la Modernidad todos saben) ya no habla nadie. 